\title{
NEW DISTRIBUTION RECORDS OF STRIGULA (STRIGULACEAE, ASCOMYCOTA) FROM THE WESTERN GHATS IN INDIA
}

\author{
Shravan Kumar Subramanya \& Yelugere Linganaik Krishnamurthy ${ }^{1}$
}

\begin{abstract}
The paper gives new records of four foliicolous lichenised fungi from the Western Ghats: Strigula melanobapha (Kremp.) R. Sant., S. nemathora Mont. f. nemathora, S. nemathora f. hypothelia (Nyl.) Lücking and S. orbicularis Fr. A brief taxonomic description, remarks, ecological notes and distribution details are provided for all the studied taxa.
\end{abstract}

Key words: biogeography, foliicolous lichens, Indian Subcontinent, Paleotropic

Shravan Kumar Subramanya \& Yelugere Linganaik Krishnamurthy, Department of Post Graduate Studies and Research in Applied Botany, Kuvempu University, Jnanasahyadri, Shankaraghatta-577451, Shimoga, Karnataka, India; e-mail: murthy_ylk@yahoo.co.in

\section{INTRODUCTION}

The study of foliicolous lichens on the Indian Subcontinent (Awasthi 2010; Singh \& Sinha 2010; Singh \& Pinokiyo 2014) is not as exhaustive as similar work on the Neotropics (Lücking 2008). Since the majority of the territory of India is situated in the tropical zone (Paleotropics), the country provides a favourable habitat for foliicolous lichens, especially in the Western Ghats. The climatic conditions also allow considerable colonisation of foliicolous lichens in the Eastern Himalayan regions. Lichenological studies in India started at the beginning of the eighteenth century (Fries 1825), much earlier than the first worldwide monograph of foliicolous lichens, published in 1952 (Santesson 1952). After that, only a few scientists worked on this group in India (Awasthi 2010; Farkas 2014). Recently, Singh and Pinokiyo (2014) worked on the foliicolous lichens of India, but their primary study site was the Eastern Himalayas and they did not made collections from the Western Ghats. Singh et al. (2004) described the Western Ghats as the region with the highest number of endemic lichens. Exhaustive collections and detailed enumeration reports of foliicolous lichens have not been done in this region.

\footnotetext{
1 Corresponding author
}

Singh (1970) reported the genus Strigula Fr. (Strigulaceae) for the first time for the Indian Subcontinent from the Andaman Islands, and described five species of Strigula along with one Raciborskiella. Later many researchers contributed to the foliicolous lichens of that genus in India (Sethy \& Patwardhan 1987; Sinha \& Singh 1987; Singh \& Pinokiyo 2003; Pinokiyo et al. 2006). Worldwide the genus is represented by 36 species and 3 subspecific taxa, among them 16 species (14 foliicolous, 2 corticolous) known from India (Singh \& Pinokiyo 2014). The genus is characterised by having a subcuticular (with few exceptions) thallus, with perithecia. Other important characters are 1-3 septate ascospores and simple or sparsely branched and anastomosed paraphyses. During a recent field survey in the Western Ghats we collected many foliicolous lichens, including several new records. In this paper we give some of these new records of the foliicolous genus Strigula.

\section{MATERIALS AND METHODS}

Foliicolous lichen specimens were collected randomly from different localities of the Western Ghats. Leaves of phorophytes reaching a height of up to 3 metres were considered for sampling. Samples of leaves colonised 
by lichens were collected in paper bags. A stereomicroscope (Carl Zeiss Stemi 2000C) was used for morphological studies and a compound microscope (Carl Zeiss Primo Star) for studying the anatomy of thalli and fruiting bodies. Anatomical characteristics were observed in hand-cut sections mounted in water and $10 \% \mathrm{KOH}(\mathrm{K})$; all measurements were taken in water. Photographs were taken with an AxioCamERc5s camera and the images were analysed using Axio Vision LE (AxioVs40 V 4.8.2.0). The hemiamyloid reaction of the ascus was studied in Lugol's solution $(0.2 \%$ I and $0.6 \% \mathrm{KI}$ ) after pretreatment with $\mathrm{KOH}$. Various standard literature sources (Santesson 1952; Farkas 1987; Awasthi 1991; Lücking 1991, 1992, 2008) were used for identification and comparison of species. Voucher specimens are deposited in LWG (Lucknow) and in the herbarium of the Department of Applied Botany, Kuvempu University, Jnanasahyadri, Karnataka, India.

\section{RESULTS AND DISCUSSION}

Strigula melanobapha (Kremp.) R. Sant.

Fig. $1 \mathrm{~A}-\mathrm{C}$

Symb. Bot. Upsal. 12: 188. 1952.

Thallus epiphyllous, subcuticular, very thin, metallic green to dark green or greenish brown and usually bordered by a thin black, sometimes interrupted line. Photobiont a species of Cephaleureos, cells in one to several layers, angular-oblong, irregularly arranged. Perithecia conical to hemispherical, greyish black (covered by thin thallus layer up to ostiole), 0.4-0.7 $\mathrm{mm}$. Ascospores hyaline, ellipsoid to fusiform, biseriate, 1-septate, rarely 3-septate, constricted at septa, $12-20 \times 3-5 \mu \mathrm{m}$, spores not breaking into halves within the asci but sometimes outside the asci in squash mount; cells with acute ends, unequal in size. Conidiomata pycnidia, numerous, black at lobe margins, basally immersed, wart-shaped; macroconidia simple, bacillar to ellipsoid, 1 -septate, $10-12 \times 2-3 \mu \mathrm{m}$ diam.

REMARKS. The species is characterised by its elongated, dichotomously branched lobes of the thallus with interrupted black-bordered margins. It can be distinguished from $S$. tremens Müll. Arg., which has smaller (ca $0.4 \mathrm{~mm}$ ) perithecia. Strigula subtilissima (Fée) Müll. Arg. and S. maculata (Cooke \& Massee) R. Sant. are also similar to $S$. melanobapha but they have oblong-bacillar ascospores $(8-18 \times 2-3 \mu \mathrm{m})$, smaller macroconidia (4-7 $\mu \mathrm{m}$ long), and the thallus is bordered by a continuous black line.

ECOLOGY AND DISTRIBUTION. It grows on leaves of Memecylon malabaricum in shola forest (montane forest). It has a pantropical distribution. In India it is reported from the Andaman Islands and Arunachal Pradesh (Singh \& Pinokiyo 2014).

Specimens examined: INDIA. Karnataka. Chikmagalur District: Chandra-Drona Parvatha: shola forest on the way to Mullaiahnagiri Peak, $13^{\circ} 23^{\prime} 25^{\prime \prime} \mathrm{N}$, $75^{\circ} 42^{\prime} 59^{\prime \prime} \mathrm{E}, 1693 \mathrm{~m}$, epiphyllous on Memecylon malabaricum (C. B. Clarke.) Cogn., 4 Dec. 2013, Shravan Kumar S. \& Y.L. Krishnamurthy 5562.

\section{Strigula nemathora Mont. f. nemathora}

Fig. 1D \& E

in Sagra, Hist. Phys. Cuba Bot. Pl. Cell. 2: 139. 1842.

Thallus subcuticular, bluish to greenish white, continuous or strongly lobate, its surface or margins densely covered with small white papillae. Photobiont Cephaleuros, cells in one to several layers, angular-rounded, irregularly arranged. Perithecia covered with thallus tissue, hence visible as brown to dark brown, involucrellum colourless, only in upper parts dark; ascospores fusiform, 15-22 × 4-6 $\mu \mathrm{m}$. Pycnidia common, macroconidia bacillar to ellipsoid, 1-septate, 9-12 $\times 2.0-3.0 \mu \mathrm{m}$; microconidia simple, fusiform, 3-4 × 1.2-1.8 $\mu \mathrm{m}$.

REMARKS. The absence of an involucrellum in the perithecia is the key character differentiating $S$. nemathora from the other species of Strigula. Strigula nemathora f. nemathora can be distinguished from the other forms of the species by

Fig. 1. A-C - Strigula melanobapha (Kremp.) R. Sant., A - thallus with perithecia, B - asci, C - ascospore. D \& E - S. nemathora Mont. f. nemathora, D - thallus with perithecia, E - ascospores. F, G \& H - S. nemathora f. hypothelia (Nyl.) Lücking, $\mathrm{F}$ - thallus with perithecia, $\mathrm{G}$ - macroconidia, $\mathrm{H}-$ microconidia. I \& J - S. orbicularis Fr., I - thallus with perithecia, J - asci and ascospores. Scale bars: $\mathrm{A}=0.1 \mathrm{~mm} ; \mathrm{B}, \mathrm{C}, \mathrm{E}, \mathrm{G}, \mathrm{H} \& \mathrm{~J}=10 \mu \mathrm{m} ; \mathrm{D}, \mathrm{F} \& \mathrm{I}=1 \mathrm{~mm}$. 

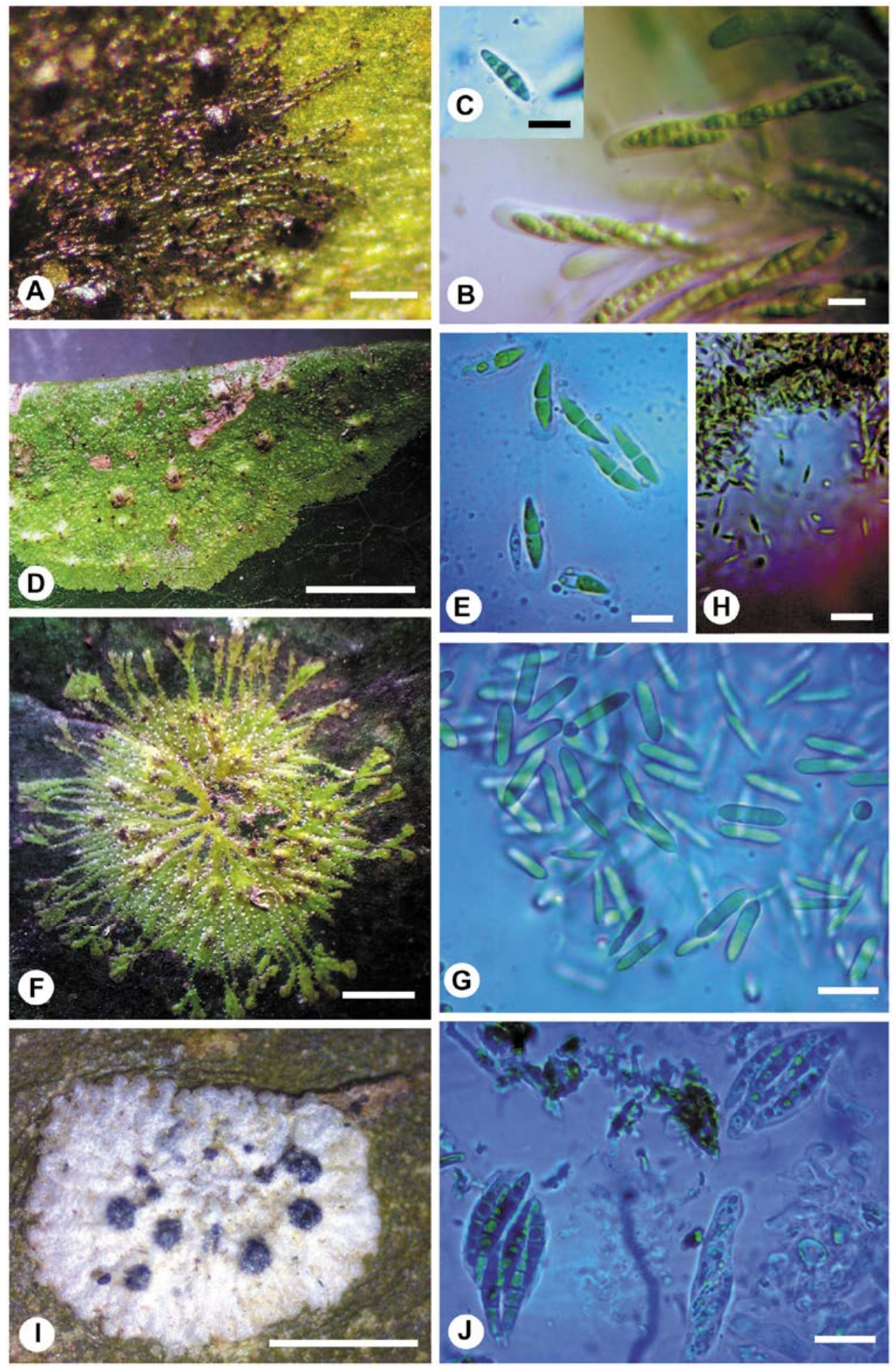
its more or less linear thalline lobes with minutely papillose margins and dissected ends.

ECOlOGY AND DISTRIBUTION. Strigula nemathora f. nemathora usually grows on leaves of Cinnamomum spp. at lower elevations in evergreen and moist deciduous forest. It has a pantropical distribution. In India it is reported from the Andaman Islands and Arunachal Pradesh (Singh \& Pinokiyo 2014).

Specimens EXAmined: INDIA. KaRnAtaka. Shimoga district: Chakranagara: evergreen forest, $13^{\circ} 48^{\prime} 52^{\prime \prime} \mathrm{N}$, $74^{\circ} 57^{\prime} 55^{\prime \prime} \mathrm{E}$, alt. $602 \mathrm{~m}$, epiphyllous on Cinnamomum malabatrum (Burman) Blume, 15 March 2013, Shravan Kumar S. \& Y.L. Krishnamurthy 5671, 5674; Tamil Nadu Nagarcoil district: moist deciduous forest, $08^{\circ} 16^{\prime} 00^{\prime \prime} \mathrm{N}$, $77^{\circ} 28^{\prime} 12^{\prime \prime}$ E, alt. 611 m, epiphyllous on Cinnamomum sp., 15 Jan. 2014, Shravan Kumar S. \& Y.L. Krishnamurthy 5703.

\section{Strigula nemathora f. hypothelia (Nyl.)}

\section{Lücking}

Fig. $1 \mathrm{~F}-\mathrm{H}$

Fl. Neotrop. Monogr. 103: 248. 2008

Thallus epiphyllous, subcuticular, greenish white, continuous or strongly lobate, its margins densely covered with small sterile verrucae visible as white papillae. Photobiont Cephaleuros, cells in one to several layers, rounded, irregularly arranged. Perithecia covered with thin thalline tissue making it concolourous with the thallus, brownish, convex, 0.4-0.6 mm diam., involucrellum colourless, only in upper ostiolar region dark; asci 8-spored; ascospores 1-septate, fusiform, 15-22 $\times 4-5 \mu \mathrm{m}$. Conidiomata not observed.

REMARKS. Strigula nemathora f. hypothelia is distinguished from $S$. nemathora f. nemathora by its interspaces in the thallus and distinctly branched lobes. The white papillae on the thallus surface and the absence of an involucrellum in the perithecia are unique characters making it easy to distinguish from other species of Strigula.

ECOlOGY AND DISTRIBUTION. It grows on leaves of Hopea parviflora Bedd, Persea macrantha (Nees) Kosterm. and Psychotria nigra (Gaertn.) Alston, observed during early winter in shola forest. It has a pantropical distribution. In
India it is reported from the Andaman Islands and Arunachal Pradesh (Singh \& Pinokiyo 2014).

Specimens examined: INDIA. Karnataka. Chikmagalur district. Kudremukh, evergreen forest, near stream in Bagavathi Nature Camp, $13^{\circ} 08^{\prime} 38^{\prime \prime} \mathrm{N}$, $75^{\circ} 15^{\prime} 33^{\prime \prime}$ E, alt. $1567 \mathrm{~m}$, epiphyllous on Persea macrantha, 18 Nov. 2011, Shravan Kumar S. \& Y.L. Krishnamurthy 5504, 5514; Chikmagalur district. Kigga, on the way to Narasimha Parvatha, shola forest, $13^{\circ} 25^{\prime} 20^{\prime \prime} \mathrm{N}, 75^{\circ} 10^{\prime} 35^{\prime \prime} \mathrm{E}$, alt. $842 \mathrm{~m}$, epiphyllous on Hopea parviflora Bedd., 14 Nov. 2013, Shravan Kumar S. \& Y.L. Krishnamurthy 5688.

\section{Strigula orbicularis Fr.}

Fig. 1I \& J

Linnaea 5: 549. 1830

Thallus epiphyllous, subcuticular, greyish to whitish green, white when dead, 5-20 mm diam., 20-30 $\mu \mathrm{m}$ thick; margins lobulate. Photobiont Cephaleuros, cells in one to several layers, angular-rounded, irregularly arranged. Perithecia wart-shaped, prominent but covered by thallus except for uppermost black part, $0.1-0.2 \mathrm{~mm}$; ascospores irregularly biseriate in the ascus, 3-septate, oblong to fusiform, 15-22 × 3-6 $\mu \mathrm{m}$. Pycnidia immersed, black, macroconidia 3-7 septate, filiform, $25-40 \times 2-2.5 \mu \mathrm{m}$, microconidia not seen.

REMARKs. The species is characterised by the absence of black marginal lines, immersed perithecia and triseptate ascospores.

ECOlOGY AND DISTRIBUtion. This species shows luxuriant growth on leaves of Dichapetalum gelonioides (Roxb.) Engl., Hopea canarensis Hole and other shrubs in dry and shady places at lower elevations in moist deciduous forest and swamp. It is known from the Andaman Islands, Arunachal Pradesh, Assam, Meghalaya and Sikkim. Globally it has a pantropical distribution (Singh \& Pinokiyo 2014).

SPECimens eXamined: INDIA. KarnataKa. Udupi district. Belthangadi: Myristica swamp forest, $13^{\circ} 04^{\prime} 37^{\prime \prime} \mathrm{N}, 75^{\circ} 14^{\prime} 46^{\prime \prime} \mathrm{E}$, alt. $246 \mathrm{~m}$, epiphyllous on Dichapetalum gelonioides (Roxb.) Engl., 24 Nov. 2012, Shravan Kumar S. \& Y.L. Krishnamurthy 5508; KeralA. Wayanad district: on the way to Sultan Batheri, moist deciduous forest, $11^{\circ} 40^{\prime} 45^{\prime \prime} \mathrm{N}, 76^{\circ} 08^{\prime} 12^{\prime \prime} \mathrm{E}$, alt. $772 \mathrm{~m}$, 
epiphyllous on Hopea canarensis Hole., 11 Nov. 2013, Shravan Kumar S. \& Y.L. Krishnamurthy 5678.

ACKNOWLedGements. We thank Dr. Robert Lücking for help with species identification and for valuable suggestions, Professor Dalip K. Upreti and Dr. Sanjeeva Nayaka, CSIR-National Botanical Research Institute, Lucknow, for their kind support, the Director of CSIRNBRI, Lucknow (LWG) for granting access to collections and for accepting our specimens for deposition, and the two anonymous reviewers for helpful remarks on the manuscript. We thank Kuvempu University, India, for providing the necessary facilities for our research, and the Department of Science and Technology, Government of India, New Delhi, for financial support (DST. F. No. SERB/SO/PS-78/2010).

\section{REFERENCES}

Awasthi D. D. 1991. A key to the microlichens of India, Nepal and Sri Lanka. Biblioth. Lichenol. 40: 1-337.

Awasthi D. D. 2010. Foliicolous lichens of the World: A review. Indian J. Forest. Additional Series 3: 1-113.

FARKas E. 1987. Foliicolous lichens of the Usambara Mountains, Tanzania I. Lichenologist 19: 43-59.

FARKas E. 2014. Bibliography of foliicolous lichenised fungi, 1952-2013. Acta Bot. Hung. 56(1-2): 33-68

FrIES E. M. 1825. Systema orbis vegetabilis. Typographia Academica, Lundae.
LÜCKING R. 1991. Neue Arten foliikoler Flechten aus Costa Rica, Zentral Amerika. Nova Hedwigia 52(3-4): 267-304.

LÜCKING R. 1992. Foliicolous lichens: A contribution to the knowledge of the lichen flora of Costa Rica, Central America. Nova Hedwigia Beih. 104: 1-179.

LÜCKING R. 2008. Foliicolous lichenized fungi. Fl. Neotrop. Monogr. 103: 1-867.

PinOKiYo A., Singh K. P. \& Singh J. S. 2006. Leaf colonizing lichens: their diversity, ecology and future prospects. Curr. Sci. 90(4): 509-518.

SANTESSON R. 1952. Foliicolous lichens. I. A revision of the taxonomy of the obligately foliicolous lichenized fungi. Symb. Bot. Upsal. 12(1): 1-590.

Sethy P. K. \& Patwardhan P. G. 1987. Some foliicolous lichens from the Nicobar and Andaman Islands, India. Biovigyanam 13(2): 52-59.

Singh A. 1970. Strigula and Raciborskiella species from the Andaman Islands, India. Bryologist 73: 719-722.

Singh K P. \& PINOKIYo A. 2003. Foliicolous lichens and their diversity in North-East India. Proc. Natl. Acad. Sci. India, $B$ 73: 177-186.

Singh K. P. \& PinOKIYo A. 2014. Foliicolous lichens of India. Bishen Singh. Indian J. Forest. Additional Series 4: 1-335.

Singh K. P. \& Sinha G. P. 2010. Indian lichens: An annotated checklist. Botanical Survey of India, Kolkata.

Singh K. P, Sinha G. P. \& Bajarbarua P. 2004. Endemic lichens of India. Geophytology 33(1/2): 1-16.

Sinha G. P. \& Singh K. P. 1987. Foliicolous lichens from Nagaland, India. Geophytology 17(2): 174-185. 